\title{
Family-Related Antecedents of Business Legality: An Empirical Investigation among Italian Family Owned SMEs
}

\author{
Gianluca Ginesti (University of Naples “Federico II” (Italy) - corresponding author) \\ Alexandra Dawson (Concordia University) \\ Salvatore Sciascia (LIUC University)
}

Final version: $\underline{\text { https://doi.org/10.1016/i.jfbs.2019.04.003 }}$

Citation for published version: Dawson, A., Ginesti, G., \& Sciascia, S. (2020). Family-related antecedents of business legality: An empirical investigation among Italian family owned SMEs. Journal of family business strategy, 11(1), 100284. 


\title{
Family-Related Antecedents of Business Legality: An Empirical Investigation among Italian Family Owned SMEs
}

\begin{abstract}
We investigate the relationship between family-related factors in family owned businesses and the level of business legality, which is a key dimension of corporate social responsibility, surprisingly neglected despite its business and social relevance. By adopting the ability and willingness perspective, and merging it with signaling theory, we consider family involvement in management and generational stage as key antecedents of legal behavior in family owned businesses. We utilize an official legality rating recently developed by the Italian Competition Authority to build a unique dataset of 161 Italian family owned SMEs. Results from a regression analysis confirm our hypotheses: business legality increases with higher levels of family involvement in management, and at later generational stages.
\end{abstract}




\section{Introduction}

Corporate social responsibility (CSR) is a key concern for family businesses (e.g., Bingham, Dyer, Smith, \& Adams, 2011; Block \& Wagner, 2014b; Cruz, Larraza-Kintana, Garcés-Galdeano, \& Berrone, 2014; Neubaum, Dibrell, \& Craig, 2012). Studies have concluded that family businesses are more socially responsible than nonfamily ones, because of concerns about image and reputation as well as the intention to protect family assets (Berrone, Cruz, Gomez-Mejia, \& Larraza-Kintana, 2010; Binz, Ferguson, Pieper, \& Astrachan, 2017; Dyer \& Whetten, 2006; Sageder, Mitter, \& Feldbauer-Durstmüller, 2018). At the same time, family businesses do not form a homogeneous group when it comes to issues of social responsibility (e.g., Block \& Wagner, 2014a, 2014b; Déniz Déniz \& Cabrera Suárez, 2005; Marques, Presas, \&Simon, 2014; Samara, Jamali, Sierra, \& Parada, 2018) - as well as CSR reporting (e.g., Cabeza- García, SacristánNavarro, \& Gómez-Ansón, 2017; Campopiano \& De Massis, 2015). In this study we investigate their heterogeneity with regard to one key dimension of CSR: the legality ofthe family business, which we define as "attachment to or observance of law or rule" (following the Oxford English Dictionary).

Corporate social responsibility is an umbrella term focusing on the relationship between business and society and, although scholars have not yet reached an exact definition (Shum \& Yam, 2011), a common theme in the literature is that firms have responsibilities to society that go beyond profit maximization (Carroll, 1979; Garriga \& Melé, 2004; Rowley \& Berman, 2000). Indeed Carroll (1991) suggested that CSR is made up not only of an economic (be profitable) dimension or responsibility, but also of a legal (obey the law) dimension, as well as the more commonly referred to ethical (do what is right) and philanthropic (contribute resources to the community and improve quality of life) dimensions, with the economic and legal dimensions being the most essential components of CSR. 
Whilst most CSR literature focuses on going beyond profitability and emphasizes the importance of ethical and philanthropic behaviors (e.g., Carroll \& Shabana, 2010), surprisingly little attention has been paid to the legal dimension of CSR (e.g., Orlitzky, Schmidt, \& Rynes, 2003). However, the legal dimension is a key dimension of CSR (Carroll, 1991), and it would be neglectful to take it for granted, because illegal behavior on the part of businesses can have grave consequences, arguably more serious than behaviors lacking in ethics or philanthropy. For example, unethical firm behaviors can have negative effects on consumer emotions, leading to consumer boycotts (Lindenmeier, Schleer, \& Pricl, 2012), damaging consumers' brand attachment and creating emotional ambivalence (Schmalz \& Orth, 2012). Illegal behaviors, i.e. those that do not comply with the formal rule of law (Webb, Tihanyi, Ireland, \& Sirmon, 2009), have more direct and detrimental effects on businesses, by causing loss of firm resources and damaging firm performance through lower accounting returns and slower sales growth over the long term (Baucus \& Baucus, 1997; Mishina, Dykes, Block, \& Pollock, 2010). In sum, both management and family business literature have paid limited attention to the legal dimension of CSR and its potentially harmful consequences.

In the present study we fill this gap in the literature by focusing on the legal dimension of CSR and some of its key antecedents. We do so by drawing on a taxonomy that has been proposed for family business heterogeneity (Hernández-Linares, Sarkar, \& López-Fernández, 2017), based on three core conceptual elements: ownership, management and continuity, with continuity defined as the successful transfer of business across generations (in our study we take this to be the generational stage of the family business). Ownership, management and generational stage are distinguishing features of family businesses, however they are associated with family-oriented particularistic behavior only if family involvement allows the family tohave the ability, i.e. the discretion, to act idiosyncratically, and the willingness, i.e. the disposition, to pursue familyoriented particularistic objectives. Furthermore, whilst ability and 
willingness each are necessary conditions for such a behavior, both need to be present, as a sufficient condition, for family involvement to lead to family-oriented particularistic behavior (De Massis, Kotlar, Chua, \& Chrisman, 2014) that goes beyond pure financial goals (Carney, 2005). Hence, it is important to consider both the family's ability and its willingness as determinants of whether family involvement leads to family-oriented particularistic behavior, which in this study is their legal behavior.

Thus, we ask the following research question in order to further our understanding of the heterogeneity of family businesses with respect to their legality: what is the relationship between family involvement in management (Sciascia \& Mazzola, 2008) and generational stage (Cruz \& Nordqvist, 2012) on the one hand and the legality of family owned businesses on the other ${ }^{1}$ ?

Our study builds on extant family business literature on CSR and the ability and willingness paradigm in family business (e.g., De Massis et al., 2014), merging them with signaling theory (e.g., Connelly, Certo, Ireland, \& Reutzel, 2011). Data collected on a unique sample of 161 Italian small and medium sized enterprises (SMEs) confirm that business legality, measured through an official legality rating recently developed by the Italian Competition Authority, increases in family owned businesses at higher levels of family involvement in management, and at later generational stages.

Our study contributes to prior literature in key ways. First, we add to CSR literature by focusing on its legal component, which has not received much attention in the literature (Orlitzky et al., 2003). Second, by considering the ability and willingness of family businesses toengage in legal behavior, we provide evidence of the diversity of family businesses with regardto their legality levels, therefore responding to the call for researchers to grasp the heterogeneity of family businesses in any business aspect (Chrisman, Sharma, \& Taggar, 2007; Memili \&

\footnotetext{
${ }^{1}$ As stated above, ownership, management and generational stage are distinguishing features of family businesses. In our study we focus on all three by considering family ownership as a pre-condition conferring the family the ability to behave in a legal manner, and family involvement in management and generational stage as our antecedents.
} 
Dibrell, 2019). In terms of practical implications, our findings question the common wisdom about the negative effects of family involvement and generational stages: since greater family involvement in management and later generational stage seem to be related with greater business legality, including professional nonfamily managers in family businesses at any cost and as soon as possible, as some suggest (Stewart \& Hitt, 2012), may not necessarily be a panacea, also with regard to enhancing business legality.

In the remainder of this paper, first, we introduce our theoretical framework and develop our research hypotheses, relating to family involvement in management and generational stage in family owned businesses. Next, we illustrate our methodology, describing our sample, variables and empirical method. Then, we illustrate our findings. Finally, we discuss our results and propose concluding remarks, including limitations of our study and directions for future research.

\section{Theoretical framework and hypotheses}

Businesses are expected to live up to several responsibilities, one of which is to fulfil aneconomic and productive function within the legal framework (Carroll, 1979). Indeed, apartfrom the economic dimension, the legal dimension is a key component of CSR (Carroll, 1991). Legality is defined by the Oxford English Dictionary as "attachment to or observance of law or rule". Laws and regulations are formal institutions (North, 1991), which establish the boundaries of entrepreneurial activity through mechanisms such as enforcement, incentives, and precepts (Webb et al., 2009). Although CSR entails 'going beyond the law', Buhmann (2006: 189) states that "to do more than the law requires, you need to know the law" and legal norms "are widely used to inform or guide action and reporting within the sphere of CSR". Some businesses that operate outside the realm of legality may still be considered legitimate if they are perceived as being "desirable, proper, or appropriate within some socially constructed system of norms,values, beliefs, and definitions" (Suchman, 1995: 574), i.e. within informal institutions (North, 
1991). Such illegal - albeit legitimate - businesses form the informal economy. However, this type of (illegal yet legitimate) business does not enjoy certain benefits deriving from legality, namely reputation effects and reduced transaction costs (Webb et al., 2009).

By making the decision to behave in a legal way and then signaling such a decision to their stakeholders, family owned businesses show their willingness to act within the boundaries of legality. By signaling their decision to act legally, family business owners are attempting to reduce information asymmetry between themselves and their stakeholders (Spence, 2002) andare indicating their willingness to create and sustain long-standing relationships withstakeholders (Campopiano \& De Massis, 2015). In this sense the legal dimension of CSR is not only a responsibility to obey the law, as Carroll (1991) meant it to be, but also a way for businesses to explicitly signal trustworthiness to the parties they interact with. Signaling means deliberately communicating positive information in order to convey positive organizationalattributes (Kirmani \& Rao, 2000). Signaling a business's decision to act legally reduces information asymmetry by conveying to other stakeholders information about the quality of the business that would otherwise be difficult to obtain and by transferring information about the business's intent when other parties may be concerned about its behavior or behavioral intentions (Connelly et al., 2011; Elitzur \& Gavious, 2003; Stiglitz, 2000). This allows 'high quality' firms to signal their quality to outsiders (such as customers, lenders, investors and so on)who may not otherwise be aware of it due to information asymmetry (Kirmani \& Rao, 2000). Trustworthiness of a country's economic actors is a key antecedent of the type and level of economic activity that takes place (Whitley, 1999). Trust, in terms of business behavior, is based on "a perception of the probability that other agents will behave in a way that is expected" (Welter \& Smallbone, 2006: 465). For example, entrepreneurs are more likely to be successful if they can build a network of trust allowing them to create legitimacy in the market (Aldrich, 2000). Another reason why trustworthiness is relevant is that legal regulations are not always 
enforceable and enforced, leaving trust to play a key role as a 'sanctioning mechanism' that complements the overall institutional framework. In this sense trust can reduce transaction costs by providing information and reducing the likelihood of opportunistic behaviour (Welter \& Smallbone, 2006).

However, not all family businesses act legally and this may depend - among other things - on their ability and willingness to do so. Ability is defined as "the discretion of the family to direct, allocate, add to, or dispose of a firm's resources" (De Massis et al., 2014: 346). Willingness is "the favorable disposition of the involved family to engage in distinctive behavior" (De Massis et al., 2014: 347), in other words "the intention or commitment to pursue family-oriented particularistic ends" (De Massis et al., 2014: 345), arising from the values, desires, and motives of the owning family. By considering family management and generational stage in family owned businesses, we attempt to tease out their ability (discretion to act) and willingness (disposition to act) to act legally. In our study we focus on family owned businesses because ownership control is a common measure for ability in family businesses (De Massis et al., 2014). Controlling ownership gives the family a remarkable ability to behave idiosyncratically (Chrisman, Chua, De Massis, Frattini, \& Wright, 2015). Thus, family ownership is a pre-condition that gives the family the ability to behave in certain ways. However, ability is a necessary but not sufficient condition. In order to be willing to act legally, family businesses need both the ability and the willingness, as a sufficient condition (De Massis et al., 2014), to do so. We consider family involvement in management (Sciascia \& Mazzola, 2008) and generational stage (Cruz \& Nordqvist, 2012) not only as drivers of additional abilityto behave legally but also as drivers of willingness that are needed to do so, thus resulting in key antecedents of legal behavior in family owned businesses. Our conceptual framework is illustrated in Figure 1.

[Insert Figure 1] 
Family involvement in management is expected to increase the likelihood that the family business will operate within the limits of legality for two reasons: first, it reinforces the ability of family members to engage in distinctive behavior - that in this case is consistent with legal requirements - because they are the dominant members on the top management team (Chrisman et al., 2015). Thanks to their monitoring power and incentives, family managers will enjoy reduced information asymmetry in the business and will have greater power to control legal allocation and use of business resources (Jensen \& Meckling, 1976). Second, it is also expected to confer willingness to engage in such idiosyncratic behavior because family members who are involved in the management of the firm are likely to act as stewards, rather than agents, towards the business as they strongly identify with it (Le Breton-Miller, Miller, \& Lester, 2011; Miller \& Le BretonMiller, 2006; Zahra, Hayton, Neubaum, Dibrell, \& Craig, 2008). We expect to see behaviors that are consistent with legal requirements for two reasons. First, since the family typically wants to preserve the business for future generations, whilst being socially responsible at the same time, we expect such idiosyncratic behavior to be associated with family members involved in management wanting to ensure that the business is operating within the limits of legality, seeing legality as a basic condition for CSR. Indeed, family businesses with greater presence of family members on the management team have been found to be more socially responsible (López-González, Martínez-Ferrero, \& García-Meca, 2018). Family businesses tend more than other types of businesses to promote relational qualities and focus on key concerns such as "being trustworthy, supporting good causes, [being] good employers, or caring about the environment" (Binz, Hair, Pieper, \& Baldauf, 2013: 7). Second, family managers will want to signal to outside stakeholders their legality by conveying positive attributes (Connelly et al., 2011) related to the legality of their operations. Internal and external stakeholders (explicitly or implicitly) often associate the family business with the managing family, thus 
anthropomorphizing the organization and viewing it as having desirable personality traits including being trustworthy and dependable (Love \& Kraatz, 2009).

Therefore, we expect the following:

Hypothesis 1. The degree of family involvement via management is positively associated with the legality of the family owned business.

Generational stage is also expected to increase the likelihood that the family business will behave within the boundaries of legality for two reasons. First, it reinforces the family's ability to engage in distinctive behavior that is associated with legality: indeed, at later generational stages, there is greater likelihood of having formal governance and control mechanisms, as well as established organizational routines limiting family members' discretionality to extract private benefits (Sciascia, Mazzola, \& Kellermanns, 2014), which may lead some family members to behave in ways that are not consistent with the rule of law. Therefore, we expect that second and, even more so, later generations will have a more professional management style (Beck, Janssens, Debruyne, \& Lommelen, 2011) than first generation family businesses, through the introduction of appropriate governance mechanisms. Second, generational stage is also expected to confer willingness to engage in distinctive law-consistent behavior because, as the family business moves from the founder-centric first generation to the second generation, it has to find new waysto renew and grow the business whilst dealing with - and moving beyond - the founder's influence and legacy (Kelly, Athanassiou, \& Crittenden, 2000). This generally means that the second generation needs greater awareness of the external environment (Cruz \& Nordqvist, 2012), which could be facilitated by the fact that the family's knowledge and experience grow over time (Bammens, Voordeckers, \& Van Gils 2008). At the same time the second generation becomes more aware of the need for the family business to adapt to the demands of the external environment (Cruz \& Nordqvist, 2012) also because it tends to have more formal education and external work experience (Kelly et al., 2000; Sonfield \& Lussier, 2004). Beyond the second 
generation, there often is more nonfamily management and a reduced family influence (Cruz \& Nordqvist, 2012). As a result, the family's prior emotional attachment to and identification with the business is reduced, i.e. there is less of a focus on socioemotional wealth preservation (GomezMejia, Cruz, Berrone, \& De Castro, 2011; Sciascia et al., 2014), with financial objectives becoming more relevant. At the same time, greater awareness of the external environment combined with increased formality and presence of nonfamily management in the business are expected to be associated with greater transparency and accountability in thebusiness.

Therefore, we expect the following:

Hypothesis 2. Generational stage is positively associated with the legality of the family owned business such that legality increases with later generations.

\section{Method}

\subsection{Data collection}

This study relied on data collected in Italy at the end of 2016. Recent academic contributions in other related fields have called attention to Italy as a setting to analyze the topic of business legality (Acconcia, Corsetti, \& Simonelli, 2014; Ganau \& Rodríguez-Pose, 2018). Specifically, scholars have pointed out that corruption and criminality are quite evident in Italy and these factors are likely to affect business practices, especially in the case of SMEs (Del Monte \& Papagni, 2007; Ganau \& Rodríguez-Pose, 2018; La Rosa, Paternostro, \& Picciotto, 2018).Indeed, Transparency International reports that Italy is perceived as being one of the most corrupted European countries ${ }^{2}$ and the World Justice Project reveals that its adherence to the ruleof law is relatively low compared to other European countries ${ }^{3}$. Such inefficiencies are detrimental for economic activities. As a result, Italy occupies a relatively weak position for a

\footnotetext{
${ }^{2}$ See https://www.transparency.org/news/feature/corruption_perceptions_index_2017.

${ }^{3}$ See https://worldjusticeproject.org.
} 
developed country in the global ranking for ease of doing business (World Bank, 2018). Thus, public opinion and authorities are paying increasing attention and expressing growing concerns about the issue of legality. In this regard, the initiative by the Italian Competition Authority (ICA), an independent government agency, to release an institutional legality rating represents a unique opportunity to identify the firm-level levels of legality.

We adopted several data sources to develop our dataset. We obtained the degree of business legality of each family business from the ICA database ${ }^{4}$, which contains a list of companies that have obtained a legality rating in the last two years. Accounting data were extracted from AIDA Bureau Van Dijk, while governance data (i.e., equity held by family,family involvement in management and generational stage) were collected both via AIDABureau Van Dijk and by searching for information on LexisNexis and company websites.

Our dataset includes those firms that obtained a legality rating ${ }^{5}$ from ICA in 2015 and 2016, with the rating still being valid at the date of data collection, i.e. October 16, 2016. We considered the population of all limited liability unlisted SMEs included in the ICA database, i.e.341 cases. Small and medium enterprises are defined according to the indications of the EU recommendation $2003 / 361$ as those companies that employ fewer than 250 persons and have an annual turnover not exceeding EUR 50 million, and/or an annual balance sheet total not exceeding EUR 43 million. We focused on SMEs because they are pillars of the European economy and of employment growth (European Commission, 2017) and are of increasing interest in the current CSR literature (Graafland, 2018).

Following Cascino, Pugliese, Mussolino, and Sansone (2010), we defined family businesses as those companies where a family owns at least $50 \%$ of the shares and at least one family member is involved in management. Based on this definition, we classified a company as

\footnotetext{
${ }^{4}$ The ICA database is publicly available at http://www.agcm.it/rating-di-legalita/elenco.html.

${ }^{5}$ Signaling through this type of official legality rating fulfills the two main characteristics of efficacious signals (Connelly et al., 2011): first, signal observability, meaning that outsiders need to be able to notice the signal (the legality rating is publicly available on a government website); and, second, signal cost, which in this case is not amonetary cost but is related to having to disclose potentially sensitive information.
} 
a family business by searching for individuals (owners and/or managers) with same last name and by searching for family ties among shareholders and managers through LexisNexis and company websites (to take into account family members who may not share the same last name). After excluding non-family businesses (57), we were left with 284 family businesses. We disregarded 123 family businesses for which we had incomplete accounting and governance information, arriving at a final dataset of 161 cases. The 161 remaining cases were representative of the population of family businesses (284) in terms of average values of the firms' characteristics, such as age, number of employees and industry. We note that all the firms included in the final dataset were characterized by the presence of a family CEO, a finding that reflects the prevalence of family leadership in family SMEs.

\subsection{Variables}

\section{Dependent variable}

Business legality was measured through the legality rating (R_LEG), a recent instrument designed by ICA in 2013 to promote regulatory actions towards legality (Pitruzzella, 2016). The rating is provided by ICA on a 7-point Likert scale on the basis of answers provided by the company to a questionnaire, which are then verified by the government agency ICA. Thequestionnaire is available on the ICA website ${ }^{6}$ and completed upon a voluntary request by the company. It is made up of three sections. Section A collects detailed information about the company's profile, such as legal form, industry, size and ownership. Section B explores whether and under what circumstances the company and/or its top managers have been accused orconvicted of several types of crimes. Questions in this section refer, for example, to compliance to tax, trade, labor, anti-trust, anti-corruption and environmental laws. Section C explores the ability of the company to contrast illegal activities in the future. Questions in this section refer,

\footnotetext{
${ }^{6}$ The electronic questionnaire is available (in Italian) at: www.agcm.it/dotcmsDOC/rating/FormularioRatingV4_4.pdf.
} 
for example, to the adoption of a code of conduct, the use of transparent payment systems and the adoption of advanced internal control mechanisms.

The rating has two years of validity since its first release and can be renewed upon the company's request. ICA systematically verifies the evidence of requirements and can revoke or decrease the rating when the company no longer complies with the requirements. The list of companies with an assigned, suspended or revoked rating is continuously updated and publicly available on the ICA website.

Our measure of legality shows some advantages compared to the existing measures available from prior research. First, the measure used enabled us to assess legality in a broad and inclusive sense, rather than focusing on a single aspect of it, which is what some prior measures have done - for instance respecting/breaking environmental law (e.g., McKendall \& Wagner III, 1997), trade law (e.g. Peterson, 2001), occupational safety and health norms (e.g., McKendall, DeMarr, \& Jones-Rikkers, 2002), accounting norms (e.g., Yiu, Wan, \& Xu, 2018), or corruption (e.g., Cosenz \& Noto, 2014). Second, differently from cases like that of Mishina et al. (2010) who measure legality in a broader sense using a dummy variable, our measure is an ordinal variable, able to capture the degree of legality rather than the fact that the company has simply broken or not the law in a certain period of time. Third, differently from cases like those of Karpoff and Lott (1993) or Baucus and Baucus (1997), who adopt an inclusive and non-dummy measure of legality, our measure appreciates not only the extent to which a company respected/broke the law, but also the adoption of specific mechanisms to prevent illegal behaviors in the future.

\section{Independent variables}

Following Sciascia and Mazzola (2008), we measured Family Involvement in Management (FIM) as the percentage of top managers belonging to the controlling family. In line with prior research (Déniz Déniz \& Cabrera Suárez, 2005; Sciascia et al., 2014), Generational Stage 
(FAM_GEN) was measured with an ordinal scale ranging from 1 (if the firm was controlled by the first generation) to 3 (if the firm was controlled by the third or subsequent generations).

Our models also included a set of specific firm-level control variables derived from prior research. More precisely, we controlled for firm size (SIZE), measured as number of employees, since prior research suggests that larger firms are subject to greater external scrutiny and community of stakeholder pressures for responsible actions than smaller firms (Lamb \& Butler, 2018; Lepoutre \& Heene, 2006). Since firms with better capital structure and higher performance have more resources for CSR and legality, we controlled for leverage (LEV) and profitability (ROA) (Labelle, Hafsi, Francoeur, \& Amar, 2018; Lopatta, Jaeschke, Tchikov, \& Lodhia, 2017). We took into account profit volatility (ROA_VOL), measured as standard deviation of ROA in the last three fiscal years, and firm age (F_AGE), since performance stability and greaterexperience are expected to support legality (Block \& Wagner, 2014b; Cruz et al., 2014). Given that social responsibility orientations may be driven by the industrial context (Campopiano \& DeMassis, 2015; Labelle et al., 2018), we controlled for industry type (SECTOR), distinguishing between manufacturing and non-manufacturing sectors. Furthermore, we included the location of headquarters (GEO_LOC), distinguishing between northern, central and southern Italy, because each geographical context has a distinctive framework setting in terms of incentives and restrictions, resource availability, institutional and regulatory conditions, and enforcement of rules and regulations (Stenholm, Acs, \& Wuebker, 2013). We also included auditor type (AUDIT) since companies audited by larger audit firms are expected to consider legality issues more carefully (Kim, Park, \& Wier, 2012; Liu, Shi, Wilson, \& Wu, 2017). Since illegality maybe prevented by the existence of monitoring mechanisms (McKendall, Sanchez, \& Sicilian, 1999), we also controlled for two important board characteristics. First, we included CEO duality (CEO DUALITY) because it may reduce board effectiveness in monitoring activities (Deman, Jorissen, \& Laveren, 2018). Second, we included the presence of female CEOs (FEM_CEO) 
because they may pay more attention to legality. Indeed, female CEOs are more likely than male CEOs to make socially responsible investments (Borghesi, Houston, \& Naranjo, 2014), to adopt stricter ethical guidelines (Lund, 2008) and to increase integrity in financial reporting (Ho, Li, Tam, \& Zhang, 2015), resulting in greater nonfinancial performance (Chadwick \& Dawson, 2018). Last, we included family involvement in ownership (FAM_OW) measured as the percentage of family ownership held by the controlling family, as it has been found to affectCSR concerns (Block \& Wagner, 2014b). All the variables adopted are described in Table 1.

[Insert Table 1 - Description of variables]

Table 2 shows the main descriptive statistics related to the variables adopted. In particular, we notice that the mean value of R_LEG is relatively low (2.96), because requirements for obtaining higher scores are very strict. The average percentage of Family Involvement in Ownership is about $86 \%$, while the average percentage of Family Involvement inManagement is $51 \%$. Lastly, the mean value of the generational stage is 2 .

[Insert Table 2 - Descriptive statistics]

\subsection{Regression model}

To identify whether and to what extent the hypothesized antecedents are associated with business legality, given the ordinal nature of the dependent variable, we employed an ordered logistic regression model with robust standards errors. We first entered the control variables and ran Model (1):

$$
\begin{aligned}
& \text { R_LEG }=\square_{0^{+}} \square_{1} S I Z E+\square_{2} L E V+\square_{3} R O A+\square_{4} R O A \_V O L+\square_{5} F_{-} A G E+\square_{6} S E C T O R+ \\
& \square_{7} G E O \_L O C+\square_{8} A U D I T+\square_{9} C E O \_D U A L T I Y+\square_{10} F E M \_C E O+\square_{11} F A M \_O W+\square
\end{aligned}
$$

\section{Model (1)}

Thereafter, we explored the impact of the proposed family-related factors by introducing further variables in Model (2): 


$$
\begin{aligned}
& \text { R_LEG }=\quad \square_{0^{+}} \quad \square_{1} S I Z E+\square_{2} L E V+\square_{3} R O A+\square_{4} R O A_{-} V O L+\square_{5} F_{-} A G E+\square_{6} S E C T O R+\square_{7} G E O \\
& L O C+\square_{8} A U D I T+\square_{9} C E O \_D U A L T I Y+\square_{10} F E M \_C E O+\square_{11} F A M_{-} O W \square \square_{12} F I M+\square_{13} F A M \_G E N+\square
\end{aligned}
$$

Model (2)

\section{Findings}

\subsection{Results}

Table 3 reports the correlations among the variables used. In line with our predictions, R_LEG is positively associated with FAM_GEN and FIM. The correlations between R_LEG and thecontrol variables have the expected signs. Although the correlation between FAM_GEN andFIM is considerable, the check of the variance inflation factors (VIFs) in the subsequent regression analysis did not show any evident multicollinearity problem (the maximum VIF was 1.53).

[Insert Table 3 - Correlation matrix]

Table 4 shows the regression results. In Model (1), we find a negative and significant coefficient for SECTOR $(\mathrm{p}<0.01)$, meaning that firms operating in the manufacturing industry tend to have lower R_LEG scores. We explain this result by the fact that non-manufacturing firms may be characterized by higher levels of professionalism and attention to reputation, whichare considered two important elements driving managers towards legality (Collins, Uhlenbruck, \& Rodriguez, 2009; Déniz Déniz \& Cabrera Suárez, 2005).

Model (2) shows a significant increase in the Pseudo $\mathrm{R}^{2}$ and confirms the significant results obtained in Model (1) for SECTOR. The regression results also reveal that the coefficient of CEO_DUALITY is negatively and significantly associated to R_LEG $(p<0.05)$, confirming that legality is greater when the role of the CEO is distinct from the role of the Chair of the Board. In line with the prediction of H1, FIM shows a positive and significant coefficient 
$(p<0.05)$, meaning that the higher the percentage of family members in the management team, the higher is business legality. Similarly, in line with the prediction of H2, FAM_GEN shows a positive and significant coefficient $(\mathrm{p}<0.01)$, suggesting that family businesses at later generational stages are characterized by a higher degree of business legality.

[Insert Table 4 - Regression results]

\subsection{Robustness tests}

We assessed the robustness of our results in several ways. First, we controlled for the existence of possible non-linear effects of FIM and GEN on our dependent variable by introducing FIM squared and FAM_GEN squared in Model (2). Results exclude any non-linear effect since the coefficients of FIM and FAM_GEN remain significant while the coefficients of FIM squared and FAM_GEN squared are not significant. Furthermore, we re-estimated Model (2) by using alternative specification of FAM_GEN (i.e. FAM_GEN=1 if the firm is controlled by the first generation and 0 otherwise) and FIM (i.e. FIM = absolute number of family managers): regression results are consistent with those discussed in section 4.1 .

Last, we investigated if results are sensitive to the inclusion of additional variables that may affect business legality. More specifically, we included the religiosity of the firm's headquarter location (REL), since Boone, Khurana and Raman (2013) document that religiosity deters an unethical behavior as tax avoidance. We added the age of the CEO (CEO_AGE), because recent research suggests that younger CEOs have a higher attitude towards legality (La Rosa et al., 2018). We included the cost of financial debt (COST_DEBT) since it has been foundto decrease investments in CSR activities (Cruz et al., 2014). Lastly, we added women's involvement in management (FEM_MAN) since female managers reveal a higher ethical sensitivity than male managers (Simga-Mugan, Daly, Onkal, \& Kavut, 2005). As shown in Table5, our main results remain substantially unaltered after including these additional four variables, thus lending further robustness to our findings. 


\section{[Insert Table 5 - Robustness regression results]}

\section{Discussion and conclusions}

In this study we contribute to filling an apparent gap in the CSR literature, which has not yet considered a key dimension of CSR (Carroll, 1991): the legal dimension (Orlitzky et al., 2003). Illegal behaviors can have direct and detrimental effects on businesses, through loss of firm resources and lower firm performance due to decreased accounting returns and slower sales growth over the long term (Baucus \& Baucus, 1997; Mishina et al., 2010). Therefore, it is important to understand the key antecedents of such a core dimension of CSR in order to shed light on what drives legal behavior of family businesses and the willingness to signal such a behavior to stakeholders.

Our study of the family-level drivers of the legality of family owned business indicates that greater family involvement in management and later generational stages, which are driversof a family's ability and willingness to engage in certain behaviors, are associated with higher levels of business legality. Legality is an essential dimension of CSR and therefore can be considered, together with the economic dimension, as driving the other two - namely ethical and philanthropic dimensions (Carroll, 1991) - on which most research about CSR in family businesses has focused (e.g., Berrone et al., 2010; Campopiano et al., 2014). In family owned businesses, where ownership control confers the family the ability to choose certain behaviors, willingness is needed, alongside ability, for the business to pursue certain behaviors. We consider family involvement in management and generational stage as key antecedents of legal behavior in family owned businesses. When more family members are involved in the management of the business, and at later generational stages, they not only have more ability but they also have the willingness to operate within the domain of legality and to signal this decision to their stakeholders. 
Deciding to signal business legality by requesting a formal recognition at an institutional level is in line with the great importance that family businesses give to their corporate reputation, which is based on family members' identification with the firm and their desire for stakeholders to perceive the firm (and the family) favorably (Deephouse \& Jaskiewicz, 2013). Our findings are also explained by the relatively small size of the firms under investigation, i.e. SMEs: smaller firms do not enjoy the same status as larger firms, which may induce stakeholders to attribute "properties and qualities, such as probity and soundness [...] on the basis of social cues", through a process known as institutional ascription (Gabbioneta, Greenwood, Mazzola, \& Minoja, 2013: 17). Indeed, smaller firms have to willingly and explicitly signal their probity and soundness by, as in this instance, applying for an official legality rating that is bestowed by a formal institution and therefore recognized by the firms' stakeholders.

Although this study does not allow us to test the mechanisms underlying the willingness to act legally, we speculate that loss aversion may be at play here, drawing on literature on the determinants of illegality, which are related to psychological processes driving decision making (Mishina et al., 2010). Based on prospect theory (Kahneman \& Tversky, 1979), decisions to act illegally are often driven by loss aversion, that is, the perception that losses are larger than gains. According to this view, individuals will behave in a risk-averse manner in order to protect sure gains and in a risk-seeking manner in order to avoid sure losses. Thus, business owners who experience expectations (e.g., from external investors or analysts) to maintain or improve their businesses' performance (and avoid future losses) are more likely to experience pressure that may lead them to act illegally (Mishina et al., 2010). Seeing that family businesses are generally driven by a long-term orientation (Le Breton-Miller \& Miller, 2006; Lumpkin \& Brigham, 2011), our findings may be explained by the fact that certain family businesses (specifically, those with greater family management and later generations) experience relatively less pressure related to short-term financial objectives, leading them to decide to act within the limits of 
legality. As well as being evaluated within the context of subjective norms deriving from family attitudes, resulting in pressure to engage (or not engage) in certain behaviors, family businesses may also perceive external social pressure (Carr \& Sequeira, 2007) to engage in legally compliant behavior. There may be a process of institutionalization at play here as a socialprocess by which individuals come to accept a shared definition of social reality and obligations (Scott, 1987), similar to the pressures often felt by family businesses to adopt a relational orientation and display social concerns (Bingham et al., 2011).

We contribute to the development of management and family business studies in two respects. First, we add to prior literature on CSR by focusing on its legal dimension, which has surprisingly received limited attention in the literature (Orlitzky et al., 2003). Specifically, with regard to CSR literature in family businesses, we contribute to the identification of some key drivers of business legality, namely family involvement in management and generational stage. Thus, we open a new issue in the scholarly debate on family businesses, i.e., what drives their legality, which has been neglected by scholars despite its practical relevance in society. Indeed, business legality is an issue that is crucial for all stakeholders: such a seminal investigation of its determinants in family businesses paves the way to new relevant studies in the family business field.

Second, we add to the debate on family business heterogeneity according to which the variance among family businesses may be even greater than the variance between family businesses and non-family businesses (Chrisman \& Patel, 2012; Memili \& Dibrell, 2019). We do so by drawing on a taxonomy that has been proposed for family business heterogeneity (Hernández-Linares, Sarkar, \& López-Fernández, 2017), based on three core conceptual elements: ownership, management and generational stage of the family business, as an indicator of continuity. Specifically, we provide evidence of the variance in family owned businesslegality by isolating two family-related antecedents of such a variance, related to the ability and 
willingness of family businesses to pursue and signal their legal behavior, as a sufficient condition for family involvement to lead to family-oriented particularistic behavior (De Massiset al., 2014). The level of legality emerges as a new additional criterion for family business heterogeneity, thus reinforcing the idea that the group of family businesses is characterized by significant differences among its members. The multiplicity of family businesses, mostly determined by the extent of family involvement and the generational stage, creates heterogeneous behaviors also in terms of legality, suggesting that family business is too narrow alabel that can induce scholars to simplistic conclusions.

The present research also has several practical implications. We show that family involvement can be beneficial - in terms of legality - for the family business, because a family business can behave 'professionally' without necessarily hiring nonfamily managers. Therefore, we side with recent literature questioning the rigid prescription of involving nonfamily managers in family businesses as soon as possible and at any cost (Stewart \& Hitt, 2012). Rather than excluding family members from the management of the firm, we suggest the introduction of adequate formal and informal governance mechanisms (e.g., an independent board of directors or a set of shared values) and the use of an incentive system oriented to focusing managers' attention on issues of legality since earlier generational stages.

Our study is not free from limitations, of course, that open the way to future research. First, this study relies on a measure of legality that covers only Italian companies and, thereby, isnot available in other geographical areas. Hence, the generalizability of our findings requires caution since our study does not take into account the impact of country-level factors that may affect the degree of the business legality. Future research may test our hypotheses in other geographical settings in order to check if results are confirmed. Indeed, family-related factors may have a different effect on legality in countries characterized by different cultures andinstitutions. Seeing that our dependent variable has largely been untested in the family business 
context, it would be fruitful to investigate it further not only within different institutional arrangements, but also to consider other contextual, family-, and business-related factors (for example different combinations of governance antecedents; see, e.g., Samara et al., 2018) that may affect legal behavior in family businesses.

Second, the legality questionnaire is completed voluntarily by companies and - while we take this as their desire to signal legal behavior - it may also introduce a selection bias. Third, we have not been able to collect additional data about family members' characteristics (e.g., level of education, religious orientation, social and political ties, professional affiliations, etc.) that may influence the willingness and engagement towards legality (Collins et al., 2009). Scholars are consequently invited to collect more primary data to grasp additional factors that may induce family businesses towards legality and may interact with our independent variables.

We also propose additional avenues for future research that are unrelated to the limitations of the present study. In particular, we suggest examining the variation in the consequences of legality among family businesses by assessing whether it may generate differentbusiness and family outcomes. In other words, it may be interesting to investigate whetherfamily businesses with higher levels of legality gain any benefit at the business level (e.g., lower cost of capital, easier access to public financing, increasing of direct foreign investments, etc.) and the family level (e.g. higher reputation, harmony, etc.).

Two more opportunities for future research can be derived from the literature on the determinants of (il)legality (Mishina et al., 2010). This literature indicates that prior gains tend to lead to higher levels of risk seeking not only because of loss aversion as outlined above (Mishina et al., 2010), but also because individuals perceive they are gambling 'house money', i.e., profits gained from prior winning bets, rather than their own capital (Thaler \& Johnson, 1990). Future research may consider whether family business owners decide to act more legally because they perceive that they are 'gambling' their own (and not somebody else's) money (Thaler \& 
Johnson, 1990). This may be more likely if their wealth is concentrated in the family business (Gomez-Mejia, Makri, \& Kintana, 2010). Furthermore, prior success and periods of high performance can induce executives to become risk seeking (i.e., act illegally) because they perceive themselves as being infallible - through so-called executive hubris (Hayward \& Hambrick, 1997). Future research may look into whether this is more likely if there are non- family managers, and also whether higher levels of family ownership together with higherethical attitudes (Bucar \& Hisrich, 2001) allow the family to monitor managers more closely.

Finally, future research could look into the role of informal laws and norms - in addition to or instead of formal ones - as they may offer a different context in which family owned businesses can operate in line with CSR behaviors; as well as into self-regulation or beyondcompliance obligations for ethical and legal conduct and their impact on behaviors and standards that may go 'above and beyond the law' (e.g., Norman, 2011) in order to fulfil their discretionary (i.e., voluntary) responsibilities (Joyner \& Payne, 2002). We encourage fellow family business and management scholars to pursue these and other research opportunities in order to further our understanding of the adoption of sustainable practices and how these might differ with varying levels and forms of family influence. 


\section{References}

Acconcia, A., Corsetti, G., \& Simonelli, S. (2014). Mafia and public spending: Evidence on the fiscal multiplier from a quasi-experiment. American Economic Review, 104(7), 21852209.

Aldrich, H. E. (2000). Entrepreneurial strategies in new organizational populations. Entrepreneurship: The Social Science View, 211-228.

Bammens, Y., Voordeckers, W., \& Van Gils, A. (2008). Boards of directors in family firms: A generational perspective. Small Business Economics, 31(2), 163-180.

Baucus, M. S., \& Baucus, D. A. (1997). Paying the piper: An empirical examination of longerterm financial consequences of illegal corporate behavior. Academy of Management Journal, 40(1), 129-151.

Beck, L., Janssens, W., Debruyne, M., \& Lommelen, T. (2011). A study of the relationships between generation, market orientation, and innovation in family firms. Family Business Review, 24(3), 252-272.

Berrone, P., Cruz, C., Gomez-Mejia, L. R., \& Larraza-Kintana, M. (2010). Socioemotional wealth and corporate responses to institutional pressures: Do family-controlled firms pollute less?. Administrative Science Quarterly, 55(1), 82-113.

Bingham, J. B., Dyer, W. G., Smith, I., \& Adams, G. L. (2011). A stakeholder identity orientation approach to corporate social performance in family firms. Journal of BusinessEthics, $99(4), 565-585$.

Binz, C. A., Ferguson, K. E., Pieper, T. M., \& Astrachan, J. H. (2017). Family business goals, corporate citizenship behaviour and firm performance: disentangling the connections. International Journal of Management and Enterprise Development, 16(1-2), 34-56. 
Binz, C., Hair Jr, J. F., Pieper, T. M., \& Baldauf, A. (2013). Exploring the effect of distinct family firm reputation on consumers' preferences. Journal of Family Business Strategy, 4(1), 311.

Block, J. H., \& Wagner, M. (2014a). The effect of family ownership on different dimensions of corporate social responsibility: Evidence from large US firms. Business Strategy and the Environment, 23(7), 475-492.

Block, J., \& Wagner, M. (2014b). Ownership versus management effects on corporate social responsibility concerns in large family and founder firms. Journal of Family Business Strategy, 5(4), 339-346.

Boone, J. P., Khurana, I. K., \& Raman, K.K. (2013). Religiosity and tax avoidance. The Journal of the American Taxation Association, 35(1), 53-84.

Borghesi, R., Houston, J. F., \& Naranjo, A. (2014). Corporate socially responsible investments: CEO altruism, reputation, and shareholder interests. Journal of Corporate Finance, 26, 164-181.

Bucar, B., \& Hisrich, R. D. (2001). Ethics of business managers vs. entrepreneurs. Journal of Developmental Entrepreneurship, 6(1), 59.

Buhmann, K. (2006). Corporate social responsibility: what role for law? Some aspects of law and CSR. Corporate Governance: The International Journal of Business in Society, 6(2),188202.

Cabeza-García, L., Sacristán-Navarro, M., \& Gómez-Ansón, S. (2017). Family involvement and corporate social responsibility disclosure. Journal of Family Business Strategy, 8(2), 109122.

Campopiano, G., \& De Massis, A. (2015). Corporate social responsibility reporting: A content analysis in family and nonfamily firms. Journal of Business Ethics, 29, 511-534. 
Campopiano, G., De Massis, A., \& Chirico, F. (2014). Firm philanthropy in small-and mediumsized family firms: The effects of family involvement in ownership and management. Family Business Review, 27(3), 244-258.

Carney, M. (2005). Corporate governance and competitive advantage in family-controlled firms. Entrepreneurship Theory and Practice, 29(3), 249-265.

Carr, J. C., \& Sequeira, J. M. (2007). Prior family business exposure as intergenerationalinfluence and entrepreneurial intent: A theory of planned behavior approach. Journal of Business Research, 60(10), 1090-1098.

Carroll, A. B. (1979). A three-dimensional conceptual model of corporate performance. Academy of Management Review, 4(4), 497-505.

Carroll, A. B. (1991). The pyramid of corporate social responsibility: Toward the moral management of organizational stakeholders. Business Horizons, 34(4), 39-48.

Carroll, A. B., \& Shabana, K. M. (2010). The business case for corporate social responsibility: A review of concepts, research and practice. International Journal of Management Reviews, 12(1), 85-105.

Cascino, S., Pugliese, A., Mussolino, D., \& Sansone, C. (2010). The influence of family ownership on the quality of accounting information. Family Business Review, 23, 246- 265.

Chadwick, I. C., \& Dawson, A. (2018). Women leaders and firm performance in family businesses: An examination of financial and nonfinancial outcomes. Journal of Family Business Strategy, 9(4), 238-249.

Chrisman, J. J., \& Patel, P. J. (2012). Variations in R\&D investments of family and nonfamily firms: Behavioral agency and myopic loss aversion perspectives. Academy of Management Journal, 55, 976-997. 
Chrisman, J. J., Chua, J. H., De Massis, A., Frattini, F., \& Wright, M. (2015). The ability and willingness paradox in family firm innovation. Journal of Product Innovation Management, 32(3), 310-318.

Chrisman, J. J., Sharma, P., \& Taggar, S. (2007). Family influences on firms: An introduction. Journal of Business Research, 60, 1005-1011.

Collins, J. D., Uhlenbruck, K. \& Rodriguez, P. (2009). Why firms engage in corruption: A top management perspective. Journal of Business Ethics, 87(1), 89-108.

Connelly, B. L., Certo, S. T., Ireland, R. D., \& Reutzel, C. R. (2011). Signaling theory: A review and assessment. Journal of Management, 37(1), 39-67.

Cosenz, F., \& Noto, G. (2014). A dynamic simulation approach to frame drivers and implications of corruption practices on firm performance. European Management Review, 11(3-4), $239-257$.

Cruz, C., Larraza-Kintana, M., Garcés-Galdeano, L., \& Berrone, P. (2014). Are family firms really more socially responsible? Entrepreneurship Theory and Practice, 38(6), 1295- 1316.

Cruz, C., \& Nordqvist, M. (2012). Entrepreneurial orientation in family firms: A generational perspective. Small Business Economics, 38(1), 33-49.

Deephouse, D. L., \& Jaskiewicz, P. (2013). Do family firms have better reputations than nonfamily firms? An integration of socioemotional wealth and social identity theories. Journal of Management Studies, 50(3), 337-360.

De Massis, A., Kotlar, J., Chua, J. H., \& Chrisman, J. J. (2014). Ability and willingness as sufficiency conditions for family-oriented particularistic behavior: Implications for theory and empirical studies. Journal of Small Business Management, 52(2), 344-364.

Del Monte, A., \& Papagni, E. (2007). The determinants of corruption in Italy: Regional panel data analysis. European Journal of Political Economy, 23(2), 379-396. 
Deman, R., Jorissen, A., \& Laveren, E. (2018). Board monitoring in a privately held firm: When does CEO duality matter? The moderating effect of ownership. Journal of Small Business Management, 56(2), 229-250.

Déniz Déniz, M. D. L. C. \& Cabrera Suárez, M. K. (2005). Corporate social responsibility and family business in Spain. Journal of Business Ethics, 56(1), 27-41.

Dyer, W. G., \& Whetten, D. A. (2006). Family firms and social responsibility: Preliminary evidence from the S\&P 500. Entrepreneurship Theory and Practice, 30(6), 785-802.

Elitzur, R., \& Gavious, A. (2003). Contracting, signaling, and moral hazard: a model of entrepreneurs, 'angels', and venture capitalists. Journal of Business Venturing, 18(6), 709725.

European Commission, (2017). Annual report on European SMEs 2016/2017, available at https://publications.europa.eu/en/publication-detail/-/publication/0b7b64b6-ca80-

$\underline{11 \mathrm{e} 7-}$

8e69-01aa75ed71a1/language-en.

Gabbioneta, C., Greenwood, R., Mazzola, P., \& Minoja, M. (2013). The influence of the institutional context on corporate illegality. Accounting, Organizations and Society, 38(67), 484-504.

Ganau, R., \& Rodríguez-Pose, A. (2018). Industrial clusters, organized crime, and productivity growth in Italian SMEs. Journal of Regional Science, 58(2), 363-385.

Garriga, E., \& Melé, D. (2004). Corporate social responsibility theories: Mapping the territory. Journal of Business Ethics, 53(1-2), 51-71.

Gomez-Mejia, L. R., Cruz, C., Berrone, P., \& De Castro, J. (2011). The bind that ties: Socioemotional wealth preservation in family firms. Academy of Management Annals, $5(1), 653-707$.

Gomez-Mejia, L. R., Makri, M., \& Kintana, M. L. (2010). Diversification decisions in family- 
controlled firms. Journal of Management Studies, 47(2), 223-252.

Graafland, J. (2018). Does corporate social responsibility put reputation at risk by inviting activist targeting? An empirical test among European SMEs. Corporate Social Responsibility and Environmental Management, 25(1), 1-13.

Hayward, M. L., \& Hambrick, D. C. (1997). Explaining the premiums paid for large acquisitions: Evidence of CEO hubris. Administrative Science Quarterly, 103-127.

Hernández-Linares, R., Sarkar, S., \& López-Fernández, M. C. (2017). How has the family firm literature addressed its heterogeneity through classification systems? An integrated analysis. European Journal of Family Business, 7(1-2), 1-13.

Ho, S. S., Li, A. Y., Tam, K., \& Zhang, F. (2015). CEO gender, ethical leadership, andaccounting conservatism. Journal of Business Ethics, 127(2), 351-370.

Jensen, M. C., \& Meckling, W. H. (1976). Theory of the firm: Managerial behavior, agency costs and ownership structure. Journal of Financial Economics, 3(4), 305-360.

Joyner, B. E., \& Payne, D. (2002). Evolution and implementation: A study of values, business ethics and corporate social responsibility. Journal of Business Ethics, 41(4), 297-311.

Kahneman, D., \& Tversky, A. (1979). Prospect theory: An analysis of decision under risk, Econometrica, 47, 263-291.

Karpoff, J.M., \& Lott, J.R., Jr. (1993). The reputational penalty firms bear from committing criminal fraud. Journal of Law \& Economics, 36, 757-802.

Kelly, L. M., Athanassiou, N., \& Crittenden, W. F. (2000). Founder centrality and strategic behavior in the family-owned firm. Entrepreneurship Theory and Practice, 25(2), 27-42.

Kim, Y., Park, M. S., \& Wier, B. (2012). Is earnings quality associated with corporate social responsibility?. The Accounting Review, 87(3), 761-796.

Kirmani, A., \& Rao, A. R. (2000). No pain, no gain: A critical review of the literature on 
signaling unobservable product quality. Journal of Marketing, 64(2), 66-79.

Labelle, R., Hafsi, T., Francoeur, C., \& Amar, W. B. (2018). Family firms' corporate social performance: A calculated quest for socioemotional wealth. Journal of Business Ethics, 148(3), 511-525.

Lamb, N. H., \& Butler, F. C. (2018). The influence of family firms and institutional owners on corporate social responsibility performance. Business \& Society, 57(7), 1374-1406.

La Rosa, F., Paternostro, S., \& Picciotto, L. (2018). Exploring the determinants of anti-mafia entrepreneurial behaviour: an empirical study on southern Italian SMEs. Entrepreneurship \& Regional Development, 30(1-2), 81-117.

Le Breton-Miller, I., \& Miller, D. (2006). Why do some family businesses out-compete? Governance, long-term orientations, and sustainable capability. Entrepreneurship Theory and Practice, 30(6), 731-746.

Le Breton-Miller, I., Miller, D., \& Lester, R. H. (2011). Stewardship or agency? A social embeddedness reconciliation of conduct and performance in public family businesses. Organization Science, 22(3), 704-721.

Lepoutre, J., \& Heene, A. (2006). Investigating the impact of firm size on small business social responsibility: A critical review. Journal of Business Ethics, 67(3), 257-273.

Lindenmeier, J., Schleer, C., \& Pricl, D. (2012). Consumer outrage: Emotional reactions to unethical corporate behavior. Journal of Business Research, 65(9), 1364-1373.

Liu, M., Shi, Y., Wilson, C., \& Wu, Z. (2017). Does family involvement explain why corporate social responsibility affects earnings management? Journal of Business Research, 75, 816.

Lopatta, K., Jaeschke, R., Tchikov, M., \& Lodhia, S. (2017). Corruption, corporate social responsibility and financial constraints: International firm-level evidence. European Management Review, 14(1), 47-65. 
Love, E. G., \& Kraatz, M. (2009). Character, conformity, or the bottom line? How and why downsizing affected corporate reputation. Academy of Management Journal, 52(2), 314335.

Lumpkin, G. T., \& Brigham, K. H. (2011). Long-term orientation and intertemporal choice in family firms. Entrepreneurship Theory and Practice, 35(6), 1149-1169.

Lund, D. B. (2008). Gender differences in ethics judgment of marketing professionals in the United States. Journal of Business Ethics, 77(4), 501-515.

López-González, E., Martínez-Ferrero, J., \& García-Meca, E. (2018). Corporate social responsibility in family firms: A contingency approach. Journal of Cleaner Production, doi.org/10.1016/j.jclepro.2018.11.251.

Marques, P., Presas, P., \& Simon, A. (2014). The heterogeneity of family firms in CSR engagement: The role of values. Family Business Review, 27(3), 206-227.

McKendall, M., DeMarr, B., \& Jones-Rikkers, C. (2002). Ethical compliance programs and corporate illegality: Testing the assumptions of the corporate sentencing guidelines. Journal of Business Ethics, 37(4), 367-383.

McKendall, M., Sánchez, C., \& Sicilian, P. (1999). Corporate governance and corporate illegality: The effects of board structure on environmental violations. The International Journal of Organizational Analysis, 7(3), 201-223.

McKendall, M. A., \& Wagner III, J. A. (1997). Motive, opportunity, choice, and corporate illegality. Organization Science, 8(6), 624-647.

Memili, E., \& Dibrell, C. (Eds.). (2019). The Palgrave Handbook of Heterogeneity Among Family Firms. Palgrave Macmillan.

Miller, D., \& Le Breton-Miller, I. (2006). Family governance and firm performance: Agency, stewardship, and capabilities. Family Business Review, 19(1), 73-87. 
Mishina, Y., Dykes, B. J., Block, E. S., \& Pollock, T. G. (2010). Why “good” firms do bad things: The effects of high aspirations, high expectations, and prominence on the incidence of corporate illegality. Academy of Management Journal, 53(4), 701-722.

Norman, W. (2011). Business ethics as self-regulation: Why principles that ground regulations should be used to ground beyond-compliance norms as well. Journal of Business Ethics, $102(1), 43-57$

North, D. C. (1991). Institutions. Journal of Economic Perspectives, 5(1), 97-112.

Neubaum, D. O., Dibrell, C., \& Craig, J. B. (2012). Balancing natural environmental concerns of internal and external stakeholders in family and non-family businesses. Journal of Family Business Strategy, 3(1), 28-37.

Orlitzky, M., Schmidt, F. L., \& Rynes, S. L. (2003). Corporate social and financial performance: A meta-analysis. Organization Studies, 24(3), 403-441.

Peterson, R. T. (2001). Small retailer and service company accuracy in evaluating the legality of specified practices. Journal of Small Business Management, 39(4), 312-319.

Pitruzzella, G. (2016). Competition policy in the Italian economy: Current developments and lines of action. Presentation to the Italian Parliament of the 2015 Annual Report of the Italian Competition Authority. Dig.: National Italian Am. B. Association L, 24, 101.

Rowley, T., \& Berman, S. (2000). A brand new brand of corporate social performance. Business \& Society, 39(4), 397-418.

Sageder, M., Mitter, C., \& Feldbauer-Durstmüller, B. (2018). Image and reputation of family firms: a systematic literature review of the state of research. Review of Managerial Science, 12(1), 335-377.

Samara, G., Jamali, D., Sierra, V., \& Parada, M. J. (2018). Who are the best performers? The environmental social performance of family firms. Journal of Family Business Strategy, $9(1), 33-43$. 
Schmalz, S., \& Orth, U. R. (2012). Brand attachment and consumer emotional response to unethical firm behavior. Psychology \& Marketing, 29(11), 869-884.

Sciascia, S., \& Mazzola, P. (2008). Family involvement in ownership and management: Exploring nonlinear effects on performance. Family Business Review, 21(4), 331-345.

Sciascia, S., Mazzola, P., \& Kellermanns, F. W. (2014). Family management and profitability in private family-owned firms: Introducing generational stage and the socioemotional wealth perspective. Journal of Family Business Strategy, 5(2), 131-137.

Scott, W. R. (1987). The adolescence of institutional theory. Administrative Science Quarterly, 32(4), 493-511.

Shum, P. K., \& Yam, S. L. (2011). Ethics and law: Guiding the invisible hand to correct corporate social responsibility externalities. Journal of Business Ethics, 98(4), 549-571.

Simga-Mugan, C., Daly, B., Onkal, D., \& Kavut, L. (2005). The Influence of Nationality and Gender on Ethical Sensitivity: An Application of the Issue Contingent Model. Journal of Business Ethics, 57 (2), 139-152.

Sonfield, M. C., \& Lussier, R. N. (2004). First-, second-, and third-generation family firms: A comparison. Family Business Review, 17(3), 189-201.

Spence, M. (2002). Signaling in retrospect and the informational structure of markets. American Economic Review, 92(3), 434-459.

Stenholm, P., Acs, Z. J., \& Wuebker, R. (2013). Exploring country-level institutional arrangements on the rate and type of entrepreneurial activity. Journal of Business Venturing, 28(1), 176-193.

Stewart, A., \& Hitt, M. A. (2012). Why can't a family business be more like a nonfamily business? Modes of professionalization in family firms. Family Business Review, 25(1), 58-86. 
Stiglitz, J. E. (2000). The contributions of the economics of information to twentieth century economics. Quarterly Journal of Economics, 115, 1441-1478.

Suchman, M. C. (1995). Managing legitimacy: Strategic and institutional approaches. Academy of Management Review, 20(3), 571-610.

Thaler, R. H., \& Johnson, E. J. (1990). Gambling with the house money and trying to break even: The effects of prior outcomes on risky choice. Management Science, 36(6), 643- 660.

Webb, J. W., Tihanyi, L., Ireland, R. D., \& Sirmon, D. G. (2009). You say illegal, I say legitimate: Entrepreneurship in the informal economy. Academy of Management Review, 34(3), 492510.

Welter, F., \& Smallbone, D. (2006). Exploring the role of trust in entrepreneurial activity. Entrepreneurship Theory and Practice, 30(4), 465-475.

Whitley, R. (1999). Divergent capitalisms: The social structuring and change of business systems. OUP Oxford.

World Bank (2018). Doing Business 2018. Reforming to Create Jobs.

http://www.doingbusiness.org/content/dam/doingBusiness/media/Annual$\underline{\text { Reports/English/DB2018-Full-Report.pdf }}$

Yiu, D. W., Wan, W. P., \& Xu, Y. (2018). Alternative Governance and Corporate Financial Fraud in Transition Economies: Evidence from China. Journal of Management. https://doi.org/10.1177/0149206318764296.

Zahra, S. A., Hayton, J. C., Neubaum, D. O., Dibrell, C., \& Craig, J. (2008). Culture of family commitment and strategic flexibility: The moderating effect of stewardship. Entrepreneurship Theory and Practice, 32(6), 1035-1054. 

Table 1 - Description of variables.

\begin{tabular}{lll}
\hline Variables & Measurement & Sources
\end{tabular}

Dependent variable:

R_LEG

Independent variables:
Net income to total assets at the

ROA_VOL

F_AGE

SECTOR

GEO_LOC

AUDIT

CEO_DUALITY

FEM_CEO

FAM_OW

FIM

FAM_GEN
Number of employees at the end of the fiscal year

Long-term debt to total assets at the end of the fiscal year end of the fiscal year

“Legality Rating” released by the Italian Competition Authority (ICA) on a 7-point Likert scale

Standard deviation of ROA in the last three fiscal years

Number of years since firm's foundation

Dummy variable equals to 1

(one) if the firm operates in a manufacturing sector, 0 (zero) otherwise

Firm location equals to 1 (one) if the firm headquarters are located in northern Italy, 2 (two) if the firm headquarters are located in central Italy, 3 (three) if the firm headquarters are located in southern Italy Dummy variable equals to 1 (one) if the firm is audited by one of the big four accounting firms, 0 (zero) otherwise Dummy variable equals to 1 (one) when the Chief Executive Officer (CEO) is also the Chair of the Board, 0 (zero) otherwise Dummy variable equals to 1 (one) if the CEO is female, 0 (zero) otherwise

Percentage of equity controlled by the owning family

Percentage of family members in the management team

Generational stage equals to 1 (one) if the firm is controlled by the first generation, 2 (two) if

the firm is controlled by the second generation, 3 (three) if the firm is controlled by
AIDA Bureau Van Dijk

Authors' elaboration on AIDA Bureau Van Dijk

Authors' elaboration on AIDA Bureau Van Dijk

Authors' elaboration on AIDA Bureau Van Dijk

AIDA Bureau Van Dijk

AIDA Bureau Van Dijk

AIDA Bureau Van Dijk

AIDA Bureau Van Dijk

AIDA Bureau Van Dijk / Company website / LexisNexis

AIDA Bureau Van Dijk / Company website / LexisNexis

AIDA Bureau Van Dijk / Company website / LexisNexis

AIDA Bureau Van Dijk / Company website / LexisNexis

Company website / LexisNexis 
Variables used in the robustness tests:

Percentage of religious marriages to total marriages in the province where the headquarters are located

CEO_AGE

COST_DEBT
Natural logarithm of the age of the CEO

Financial interests scaled by financial debt at the end of the fiscal year
ISTAT Database

AIDA Bureau Van Dijk / Company website / LexisNexis

AIDA Bureau Van Dijk 
Table 2 - Descriptive statistics.

\begin{tabular}{|c|c|c|c|c|c|}
\hline Variables & Observations & Mean & $\begin{array}{c}\text { Std. } \\
\text { Deviation }\end{array}$ & Min. & Max. \\
\hline R_LEG & 161 & 2.968 & 1.468 & 1 & 7 \\
\hline SIZE & 161 & 74.006 & 49.136 & 5 & 238 \\
\hline LEV & 161 & 0.590 & 0.207 & 0.028 & 0.928 \\
\hline $\mathrm{ROA}$ & 161 & 0.046 & 0.064 & -0.128 & 0.391 \\
\hline ROA_VOL & 161 & 0.024 & 0.031 & 0.000 & 0.225 \\
\hline F_AGE & 161 & 31.114 & 14.018 & 6 & 80 \\
\hline SECTOR & 161 & 0.652 & 0.477 & 0 & 1 \\
\hline GEO_LOC & 161 & 1.571 & 0.826 & 1 & 3 \\
\hline AUDIT & 161 & 0.105 & 0.308 & 0 & 1 \\
\hline CEO_DUALITY & 161 & 0.670 & 0.471 & 0 & 1 \\
\hline FEM_CEO & 161 & 0.173 & 0.380 & 0 & 1 \\
\hline FAM_OW & 161 & 0.861 & 0.166 & 0.5 & 1 \\
\hline FIM & 161 & 0.509 & 0.186 & 0.08 & 0.83 \\
\hline FAM_GEN & 161 & 2.049 & 0.748 & 1 & 3 \\
\hline
\end{tabular}


Table 3 - Correlations matrix. 
Table 4-Regression results.

\begin{tabular}{|c|c|c|}
\hline & $\begin{array}{c}\text { DEPENDENT VARIABLE: } \\
\text { R_LEG } \\
\text { Model (1) }\end{array}$ & $\begin{array}{c}\text { DEPENDENT } \\
\text { VARIABLE: } \\
\text { R_LEG } \\
\text { Model (2) }\end{array}$ \\
\hline CI7F & $\begin{array}{c}0.005 \\
(0.003)\end{array}$ & $\begin{array}{c}0.005 \\
(0.003)\end{array}$ \\
\hline I EV & $\begin{array}{c}0.311 \\
(0.886)\end{array}$ & $\begin{array}{c}0.658 \\
(0.825)\end{array}$ \\
\hline $\mathrm{R} \cap \Delta$ & $\begin{array}{l}-1.028 \\
(3.011)\end{array}$ & $\begin{array}{l}-1.377 \\
(3.257)\end{array}$ \\
\hline ROA_VOL & $(6.333)$ & $\begin{array}{c}4.631 \\
(5.589)\end{array}$ \\
\hline F_AGE & $\begin{array}{l}\text { v.uus } \\
(0.012)\end{array}$ & $\begin{array}{l}-0.020 \\
(0.013)\end{array}$ \\
\hline CERTAD & $\begin{array}{c}-0.971 * * \\
(0.362)\end{array}$ & $\begin{array}{c}-0.866^{*} \\
(0.348)\end{array}$ \\
\hline GEO_LOC & $\begin{array}{l}\text { ט.Jy1 } \\
(0.229)\end{array}$ & $\begin{array}{c}0.440 \\
(0.230)\end{array}$ \\
\hline AUDIT & $\begin{array}{l}\text { (u.Juy } \\
(0.534)\end{array}$ & $\begin{array}{c}0.754 \\
(0.537)\end{array}$ \\
\hline CEO_DUALITY & $\begin{array}{l}- \text { - } \\
(0.359)\end{array}$ & $\begin{array}{c}-0.725^{*} \\
(0.367)\end{array}$ \\
\hline FEM_CEO & $\begin{array}{l}\text { u.vy4 } \\
(0.395)\end{array}$ & $\begin{array}{l}-0.139 \\
(0.425)\end{array}$ \\
\hline 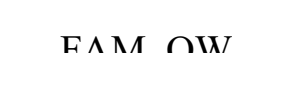 & $\begin{array}{l}-0.398 \\
(0.736)\end{array}$ & $\begin{array}{l}-0.759 \\
(0.837)\end{array}$ \\
\hline $\begin{array}{c}\text { FIM } \\
\text { FAM_GEN }\end{array}$ & & $\begin{array}{l}2.343 * \\
(0.977) \\
0.065 * * \\
(0.229)\end{array}$ \\
\hline $\begin{array}{l}\text { Observations } \\
\text { Wald Chi-square } \\
\text { Pseudo R-square }\end{array}$ & $\begin{array}{c}161 \\
26.71 * * \\
0.049\end{array}$ & $\begin{array}{c}161 \\
59.51^{* * * *} \\
0.088\end{array}$ \\
\hline
\end{tabular}



Table 5 - Robustness regression results.

\begin{tabular}{|c|c|c|c|c|}
\hline & $\begin{array}{l}\text { Dependent } \\
\text { variable: } \\
\text { R LEG }\end{array}$ & $\begin{array}{l}\text { Dependent } \\
\text { variable: } \\
\text { R LEG }\end{array}$ & $\begin{array}{l}\text { Dependent } \\
\text { variable: } \\
\text { R LEG }\end{array}$ & $\begin{array}{l}\text { Dependent } \\
\text { variable: } \\
\text { R LEG }\end{array}$ \\
\hline SI7F & $\begin{array}{c}0.005 \\
(0.003)\end{array}$ & $\begin{array}{c}0.005 \\
(0.003)\end{array}$ & $\begin{array}{c}0.005 \\
(0.003)\end{array}$ & $\begin{array}{c}0.005 \\
(0.003)\end{array}$ \\
\hline $\mathbf{I} \mathbf{F V}$ & $\begin{array}{c}0.659 \\
(0.825)\end{array}$ & $\begin{array}{c}0.648 \\
(0.821)\end{array}$ & $\begin{array}{c}0.598 \\
(0.827)\end{array}$ & $\begin{array}{c}0.682 \\
(0.837)\end{array}$ \\
\hline $\mathrm{R} \cap \Delta$ & $\begin{array}{l}-1.360 \\
(3.280)\end{array}$ & $\begin{array}{l}-1.503 \\
(3.313)\end{array}$ & $\begin{array}{l}-1.598 \\
(3.257)\end{array}$ & $\begin{array}{l}-1.412 \\
(3.315)\end{array}$ \\
\hline ROA_VOL & $\begin{array}{l}4.318 \\
(6.032)\end{array}$ & $\begin{array}{c}4.771 \\
(6.027)\end{array}$ & $\begin{array}{c}4.943 \\
(5.989)\end{array}$ & $\begin{array}{c}4.918 \\
(5.993)\end{array}$ \\
\hline F $\Delta$ CF & $\begin{array}{l}-0.021 \\
(0.014)\end{array}$ & $\begin{array}{l}-0.019 \\
(0.014)\end{array}$ & $\begin{array}{c}-0.019 \\
(0.014)\end{array}$ & $\begin{array}{c}-0.019 \\
(0.014)\end{array}$ \\
\hline SFrTAR & $\begin{array}{c}-0.868^{*} \\
(0.350)\end{array}$ & $\begin{array}{c}-0.848^{*} \\
(0.344)\end{array}$ & $\begin{array}{c}-0.847^{*} \\
(0.346)\end{array}$ & $\begin{array}{c}-0.822 * \\
(0.357)\end{array}$ \\
\hline GEO_LOC & $\begin{array}{l}\text { U.48ð } \\
(0.371)\end{array}$ & $\begin{array}{c}0.498 \\
(0.377)\end{array}$ & $\begin{array}{c}0.473 \\
(0.380)\end{array}$ & $\begin{array}{c}0.483 \\
(0.382)\end{array}$ \\
\hline AUDIT & $\begin{array}{l}\text { U. } / 24 \\
(0.542)\end{array}$ & $\begin{array}{c}0.740 \\
(0.545)\end{array}$ & $\begin{array}{c}0.733 \\
(0.549)\end{array}$ & $\begin{array}{c}0.738 \\
(0.547)\end{array}$ \\
\hline CEO_DUALITY & $\begin{array}{l}-0 . / 2 /^{\circ} \\
(0.368)\end{array}$ & $\begin{array}{c}-0.713^{*} \\
(0.364)\end{array}$ & $\begin{array}{c}-0.711 \\
(0.363)\end{array}$ & $\begin{array}{c}-0.728^{*} \\
(0.367)\end{array}$ \\
\hline FEM_CEO & $\begin{array}{l}-0.153 \\
(0.444)\end{array}$ & $\begin{array}{c}-0.157 \\
(0.448)\end{array}$ & $\begin{array}{c}-0.085 \\
(0.463)\end{array}$ & $\begin{array}{c}-0.119 \\
(0.474)\end{array}$ \\
\hline $\mathrm{F} \Delta \mathrm{M} \cap \mathrm{OW} /$ & $\begin{array}{l}-0.756 \\
(0.837)\end{array}$ & $\begin{array}{c}-0.779 \\
(0.822)\end{array}$ & $\begin{array}{c}-0.759 \\
(0.823)\end{array}$ & $\begin{array}{l}-0.739 \\
(0.825)\end{array}$ \\
\hline FIM & $\begin{array}{l}2.359^{*} \\
(0.975)\end{array}$ & $\begin{array}{l}2.446^{*} \\
(0.994)\end{array}$ & $\begin{array}{l}2.559^{*} \\
(1.034)\end{array}$ & $\begin{array}{l}2.574^{*} \\
(1.038)\end{array}$ \\
\hline F $\Delta M A$ CFN & $\begin{array}{c}0.653 * * \\
(0.229)\end{array}$ & $\begin{array}{c}0.664 * * \\
(0.234)\end{array}$ & $\begin{array}{l}0.638^{*} \\
(0.250)\end{array}$ & $\begin{array}{l}0.643^{*} \\
(0.250)\end{array}$ \\
\hline R FI & $\begin{array}{c}-0.004 \\
(0.023)\end{array}$ & $\begin{array}{l}-0.005 \\
(0.024) \\
-0.668 \\
(0.762)\end{array}$ & $\begin{array}{c}-0.005 \\
(0.024) \\
-0.675 \\
(0.756) \\
-0.472 \\
(0.978)\end{array}$ & $\begin{array}{c}-0.005 \\
(0.024) \\
-0.637 \\
(0.764) \\
-0.484 \\
(0.978) \\
0.024 \\
(0.026)\end{array}$ \\
\hline $\begin{array}{l}\text { Observations } \\
\text { Wald Chi-square } \\
\text { Pseudo R-square }\end{array}$ & $\begin{array}{c}161 \\
59.73 * * * \\
0.09\end{array}$ & $\begin{array}{c}161 \\
58.12^{* * *} \\
0.09\end{array}$ & $\begin{array}{c}161 \\
58.26^{* * *} \\
0.09\end{array}$ & $\begin{array}{c}161 \\
58.13^{* * * *} \\
0.09\end{array}$ \\
\hline
\end{tabular}


Figure 1 - Conceptual model.

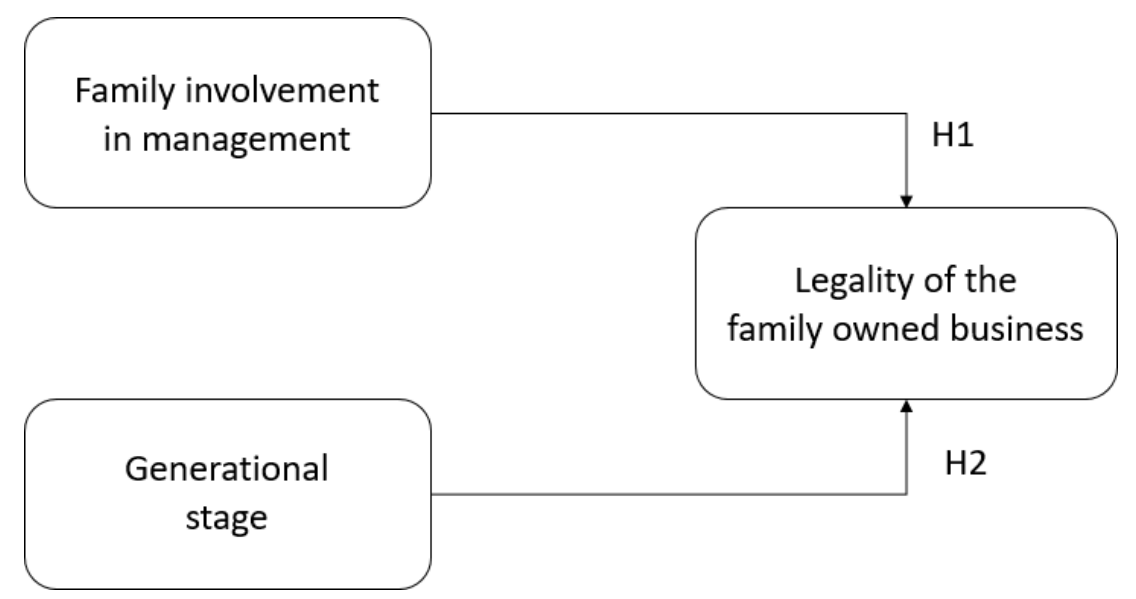

